\title{
Assessment and Management of Banking Risks in the Global Community: Benefits and Challenges of Implementation of Basel Standards
}

\author{
Kristina A. Kazakova ${ }^{1}$, Alexander G. Knyazev ${ }^{1}$, Oleg A. Lepekhin ${ }^{1}$ \& Ella I. Skobleva ${ }^{1}$ \\ ${ }^{1}$ Astrakhan State University, Astrakhan, Russia \\ Correspondence: Oleg A. Lepekhin, Astrakhan State University, Tatischeva, 20A, 414056 Astrakhan, Russia. \\ Tel: 79-64-889-8659. E-mail: okmb07@yandex.ru
}

Received: April 7, 2015 Accepted: May 12, 2015 Online Published: July 15, 2015

doi:10.5539/ass.v11n20p141 URL: http://dx.doi.org/10.5539/ass.v11n20p141

\begin{abstract}
Regulation of banking risks by the state is due to the specifics of banking, associated with the transformation of deposits into loans and multiform negative effects that banking risks bear to the national economy. Since the late 1980 s, the international practice of assessment and management of banking risks began to be reflected in the documents of the Basel Committee on Banking Supervision. In this paper we consider the evolution of Basel standards from Basel I to Basel III, and discuss substantial features of each generation of the standards. To date, a considerable number of countries, including Russia, have joined Basel standards. The paper discusses the features of regulation of banking risks in Russia, as well as the problems faced by commercial banks and the regulator in the implementation of Basel standards in the Russian banking sector.
\end{abstract}

Keywords: risk management, banking sector, Basel standards, Basel III

\section{Introduction}

The problem of assessment and management of banking risks in a rapidly changing situation in the global economy, accompanied by financial instability and desire of banking entities to permanent progressive development, acquires today a global character. Banking theory and practice in today's realities needs to develop a systematic approach to the assessment and management of financial risks. Currently accepted standards of banking supervising authorities are based on assumptions about the importance of determining the level of capital that reduces the risk of bankruptcy.

In the work of Freixas and Rochet (Freixas \& Rochet, 2008) is noted that financial markets are characterized by various forms of information asymmetry: ex ante (adverse selection), interim (moral hazard), and ex post (costly state verification). In determining the state policy of regulation of the banking sector the central problem is "moral hazard", which in banking refers to the desire of owners and/or managers of banks to conduct operations with high profitability by transferring its inherent risks to the third party, who may be depositors, other creditors and the state.

By its very nature, any financial institution, when implementing procedures aimed at the prevention of banking risks, seeks to maximize the profit from operations by effective use of funds. Thus, if we talk about the level of capital adequacy, the representatives of the banking sector prefer to operate with minimum capital in order to provide growth of assets and profitability. This in turn contradicts the ideas of supervising authorities in the banking sector, who on the other hand believe that it is the high level of capital that can help to reduce the level of bankruptcies.

The increasing complexity of banking activities, the emergence of new risks faced by banks in their operations, the rapid changes in the environment - all of this requires constant revision of approaches to assessment of the level of capital adequacy. It is important to note that activities of many large banking institutions have today an international character, which in turn explains the need to establish common standards for capital and methods of its estimation. The development of relevant standards is carried out by the Basel Committee on Banking Supervision (BCBS). The result of its work is the adoption of agreements, which regulate the procedure of capital adequacy assessment of commercial banks. 


\section{Materials}

Since the early 1980s the problem of banks' capital adequacy and assessment methodology was the subject of lively debate in the international financial institutions. Interest of regulators to bank capital is due to the fact that it performs the function of protection of depositors from possible losses. The size of the bank's capital is a key factor in the confidence of depositors and clients of the bank's ability to compensate for losses. As a result, the concept of a minimum level of capital adequacy has been proposed.

In July 1988 G-10 (the Group of Ten) countries adopted a common approach to capital adequacy, developed by the Basel Committee on Banking Supervision, which became known as the Basel Capital Accord of 1988 (BCBS, July 1988).

This agreement, known as Basel I, and the subsequent documents of the Basel Committee, regulating the assessment and management of risks, formed the information base of this article. In addition, regulations of the Bank of Russia (instructions, manuals, etc.), publications of scientific and business community were used.

\section{Results}

At present, a large number of studies has appeared assessing the impact of the established, by banking supervisory authorities, requirements for the capital adequacy and the reserve fund for unforeseen losses. Among these, we should mention impact studies of the Basel Committee which reflect the timeline of all changes in the adopted texts of agreements, as well as evaluate the effectiveness of their implementation in banking activities (for example, BCBS, April 1988).

In (Akhtaruzzaman, 2009) the author evaluates the effects of the introduction of international standards for capital adequacy requirements, and carries out a comparative analysis of the requirements of Basel I and Basel II. The author concludes that the introduction of the latest techniques increases capital requirements almost twice.

Russian publications on standards, developed by the Basel Committee on Banking Supervision, are mostly descriptive. A number of studies reveal main aspects of Basel standards (Astrelina, 2005), analyze some approaches, proposed in the BCBS documents, for example, assessment of operational or credit risks (Zolotarev, 2005), discuss the possibility of implementation of new standards in Russian banks (Tysyachnikova, 2008).

Despite the large number of studies, the effectiveness of the Basel directives in terms of flexibility of methods for assessment and management of bank risks remains open today. In the modern era of globalization accompanied by financial and economic instability, it is essential to identify the problems of introducing common standards and to identify ways to address them in order to develop an effective mechanism for prevention of financial risks in the banking business.

In the generally accepted standards, developed by the Basel Committee on Banking Supervision, you can trace the evolution of capital adequacy requirements aimed to prevent financial losses. Thus, Basel I, adopted in 1988, introduced in banking practice the principle of calculating capital adequacy ratio, which was based on structuring capital into Tier I (core) and Tier II capital. Permanent shareholder's equity, as well as all the disclosed reserves, including retained profit and reserves to cover unexpected losses, were referred to Tier I capital, while Tier II capital included more doubtful elements of the capital, such as undisclosed reserves, revaluation reserves and subordinated term debt.

Capital adequacy was assessed by a weighted risk ratio in which capital is related to different categories of assets or off-balance-sheet exposure, weighted according to broad categories of relative riskiness (Basle Committee on Banking Supervision, July 1988). It was decided to differentiate all the assets on the degree of exposure into five groups, for which have been identified certain weighting values: $0,10,20,50$ and 100 - the higher the risk, the greater the weight. On the one hand, it has allowed to differentiate between capital requirements for banks with different structure of assets. However, the simplified nominal scale did not allow to exactly define the required level of capital adequacy.

Due to its simplified approach and low sensitivity to the gradations of risk, the standard methodology of the Basel Committee became an object of criticism from the banking community. A significant drawback, for example, was the assignment of all corporate loans regardless of their credit quality to the assets with a $100 \%$ risk. As a result, lending to a borrower with the highest AAA rating could require the same volume of the reserved capital as loans to venture funds.

The new Basel Capital Accord, so-called Basel II Capital Accord, which came into force only in 2006, was published in 2004. The main objectives of Basel II were to introduce into banking practices such innovations as stimulation of banking institutions to continually improve their techniques and procedures for risk assessment 
and management, the urge for flexible and precise risk assessment, in particular through the inclusion of operational risk, the desire to reduce the gap between the minimum requirements for capital adequacy and economic evaluation of banking capital requirements.

Basel II (BCBS, June 2006), which is a more detailed document than Basel I, included such components as:

- minimum capital requirements, which differed in the complexity of approaches to the calculation of capital reserved against the relevant types of risk - credit, market or operational;

- monitoring procedures that involve certain principles of control by the regulatory authorities for capital adequacy and banks' risk assessment systems;

- market discipline, which strengthened disclosure requirements about the risks and the capital of banking institutions.

It should be noted that, as in the first document of the Basel Committee on Banking Supervision, the basic indicator variable of Basel II was the capital adequacy ratio, which recommended value was left unchanged at $8 \%$. The innovative features in the Basel II standard were new methods of assessment of various types of risks. For example, for credit risk assessment banking entities were proposed to use such options as the standardised approach and the internal ratings-based (IRB) approach. In the case of the standardised approach the methodology of Basel I was used, with the difference that assets were weighted by risk, depending on the credit rating assigned by external credit assessment institution. When using the approach based on internal ratings, risk assessment of assets was carried out via bank's internal rating model, which should be previously approved by the supervising authority.

It is important to note that an improved mechanism for calculating the minimum capital adequacy ratio, provided for Basel II, was supplemented by a system of supervision and cooperation between banks and supervisory authorities, as well as an extensive system of disclosure.

Table 1. Terms of global implementation of Basel III

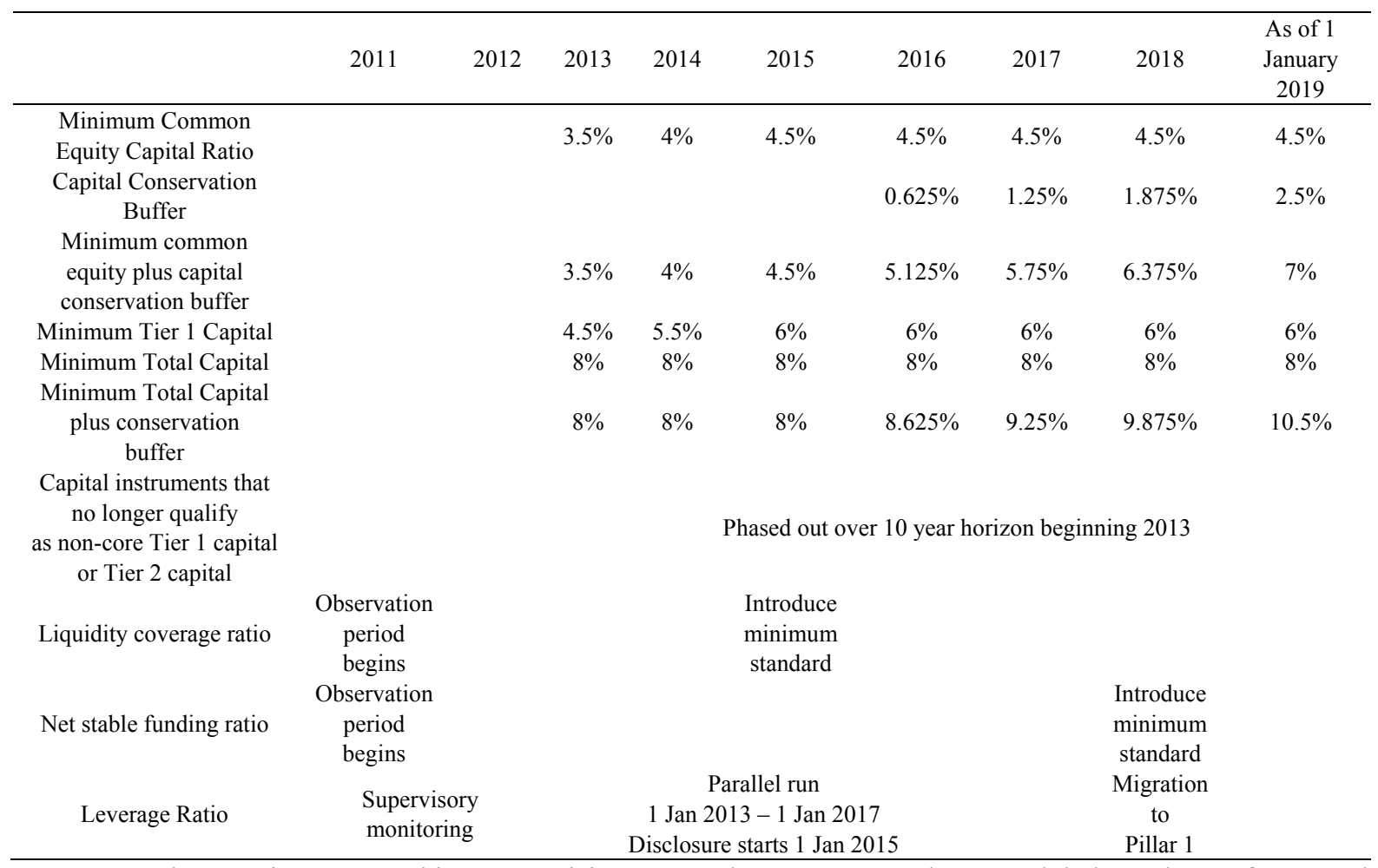

Source: Basel Committee on Banking Supervision, December 2010. "Basel III: A global regulatory framework for more resilient banks and banking systems".

Basel III, adopted in December 2010 (BCBS, December 2010), has emerged as a reaction to the global financial crisis of 2008, which in turn threatened the capital adequacy of most banking institutions. Numerous write-offs 
of bad loans were recorded as a loss of the corresponding period and reduced the amount of capital of credit institutions. In this regard, in order to maintain a sufficient amount of capital of commercial banks, governments and central banks were induced to provide banking sector with subordinated loans, which are eligible for inclusion in the capital base. According to the requirements in respect of capital, Basel III discussed such innovations as changes in the structure of banks' equity capital, increased capital requirements of the institution, as well as the creation of additional capital buffers (BCBS, September 2010).

According to the new standard, the main measure of the effectiveness of bank capital should be the possibility of its appropriate use for compensation for financial losses. Basel III thus revised capital structure, namely proposed to exclude from equity a number of elements, which are not sufficiently liquid and can not be used to cover the losses. It is important to note that the Basel III in respect of the calculation of capital adequacy does not make any changes, but only increases minimum levels of a number of ratios. For example, minimum Tier 1 capital was set at $6 \%$.

In addition to the above, the Basel III proposed a phased introduction of the two capital buffers: capital conservation buffer and countercyclical buffer. Creating a conservation buffer implies the formation of a reserve stock of capital in the amount of $2.5 \%$ of the risk which should be maintained by the bank. Countercyclical buffer is aimed to contain the credit activity of banks in times of economic recovery and stimulate it in times of recession.

The question of the flexibility of the Basel directives was raised repeatedly. The main reason for this, of course, is the difficulty of adaptation of the features of banking structures of emerging markets economies to international standards in the field of banking supervision and control. Introduction of international financial risk assessment and management standards to the Russian banking theory and practice is also ambiguous.

The Russian banking practice today is trying to introduce comparable with the characteristics of the existing banking system regulations of Basel II. The requirement to maintain market discipline is met: banking institutions disclose basic information about the capital adequacy on official sources.

Table 2. Terms of implementation of Basel III in Russia

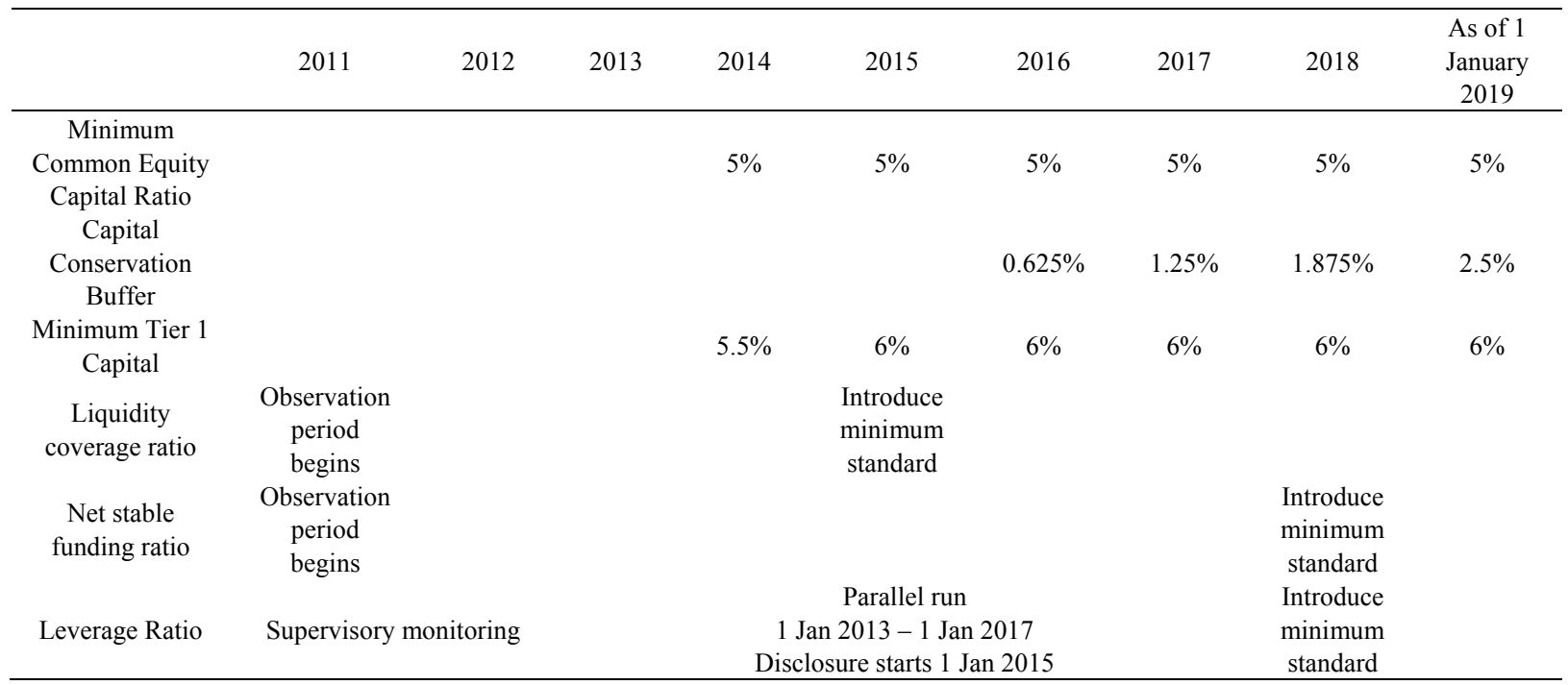

Source: Central Bank of Russia, 2011. "Banking sector development strategy of the Russian Federation for the period up to 2015", press-releases of Central Bank of Russia.

In April 2011, the Russian Government and the Bank of Russia issued a joint statement on the banking sector development strategy of the Russian Federation for the period up to 2015. Appendix 1 of this application is fully dedicated to the direction and timing of the implementation of the Basel II and Basel III standards in Russia. However, the subsequent implementation of the Basel standards required an adjustment of the time frame, as was noted in the press release of the Bank of Russia (Table 2).

Regulation adopted by the Bank of Russia of 26.03.2004 № 254-P “On the order of formation of reserves for possible losses on loans by credit organizations" (the Bank of Russia, 2004) was to a certain extent the first 
attempt in the direction of approaching the requirements of Basel I. Guided by this document, the banking practice in order to determine the estimated amount of provision classifies all loans into appropriate quality categories - standard, substandard, doubtful, problem, uncollectable, - each of which is characterized by a certain level of its depreciation - $0 \%, 1-20 \%, 21-50 \%, 51-100 \%, 100 \%$, respectively. The main disadvantage of this regulation is ranking on a nominal scale, accompanied by vague recommendations on the formation of reserve funds for the various categories of loans. On the example of the category of "doubtful loans" it is easy to see that the estimated range of depreciation of issued loan is in the interval of 21 to $50 \%$, leading to some uncertainty as to the required size of the reserve. . It is important to emphasize that the prevention of credit risk in excess of the required allocations to the reserve fund not only provides the irrationality of banking activities, the main purpose of which is to maximize profits, but also reduces the effective rate of placement because of the additional allocations to the reserve fund of the loan. This in turn gives rise to the base interest rate risk associated with the uncertainty of future profitability of the banking portfolio (Sevruk, 2010).

As part of the implementation of the standardised approach to risk assessment in 2012, the Central Bank of Russia has approved the Regulations on mandatory ratios of banks (the Bank of Russia, 2012), which sets numerical values and methodology for calculating capital adequacy, liquidity, maximum risk per borrower or group of related borrowers, and other mandatory ratios banks. The weighting factors underlying the calculation methodology, are established by the regulator on several large groups of loans, they are the same for all banks and equally applied to all loans within the same group regardless of the level of risk an individual asset.

It is important to note that today, the majority of banking institutions in Russia and a considerable number of their large corporate clients do not have ratings by international agencies that spontaneously increases the requirements for the formation of bank capital and thereby limits the ability of the banking sector to expand the scope of its activities.

At the same time we should not forget that Basel II provides alternative methods of calculating the amount of credit risk on the basis of internal ratings, allowing banking institutions to independently assess credit risk. When using the above mentioned approach banking institutions are provided with the possibility of introducing their own internal statistical models and risk assessment systems which allow to determine the probability of default (PD) of the borrower, the level of loss given default (LGD), the exposure at default (EAD), and if necessary, effective maturity $(\mathrm{M})$. As a consequence, the implementation of appropriate methodologies gives banks the opportunity to fully manage their risks and to consider them when calculating capital adequacy.

To date, the Russian banking practice begins to actively take actions in the direction of the transition from the standardised approach to credit risk and capital adequacy to advanced IRB methods. In 2012, the Central Bank of Russia published guidelines for the implementation of the approach to the assessment of credit risk based on banks' internal ratings (the Bank of Russia, December 2012). In early 2014 the Bank of Russia published draft Regulation "On the procedure for assessment the value of the credit risk based on internal ratings" (the Bank of Russia, February 2014a) and the Directive "On the order of consideration of applications of banks on the use of an IRB approach to credit risk assessment" (the Bank of the Russian Federation, February 2014b). Developed to implement appropriate standards of Basel II in Russia, these projects mainly determine the order of the transition of Russian banks on the advanced approach to the assessment and management of credit risk and describe minimum requirements for banking institutions wishing to calculate capital requirements based on these techniques.

For the implementation of credit risk assessment based on internal ratings, banks will need to obtain permission of the Bank of Russia, which will be issued by the regulator as a result of detailed checks on compliance with the minimum quantitative and qualitative requirements specified in the relevant project. It is important to note that for the submission of the application, there is a specific list of requirements, including: the size of the bank's assets should be more than 500 billion rubles, at the time of submission of the application banking institution should practice an appropriate approach in accordance with the requirements of the Bank of Russia at least two years, as well as should be presented an analysis assessing the impact of the transition to the level of capital adequacy.

\section{Discussion}

Despite the expected benefits from the implementation of the above-mentioned requirements of Basel II, the transition to the new standards involves significant time and financial costs. To create an integrated risk management system and eliminate existing inconsistencies banks will require significant investment in the development of new methodologies and tools, as well as staff training and reorganization of internal processes. Banks operating in developed markets, over a long period of time have been investing in the development and 
modernization of risk management systems. Over the years they have accumulated detailed statistics and have arranged the process of calculating capital.

Today in Russia, most financial institutions still do not have such an experience, and so the process of submission of the application and preparation for the implementation of the Basel regulations require them to solve a specific problem. It is important to understand that the use of quantitative methods of bank risks is based on the construction of mathematical models, which in turn allow us to determine the probability of crisis events, and requires a great deal of information provision. The main problem in creating such models for the Russian banking practice is insufficient and sometimes complete lack of any historical data for the respective characteristics of transactions and customers. In this case, the general statistics sometimes also does not exist or they are not applicable in connection with the specific features of the bank or lending policies. However, these difficulties should not become a stumbling block to the creation and implementation of quantitative methods for assessing credit risks. At the initial stage they can use data that have been publicly disclosed, allowing one hand to take the first step towards the development of these techniques, and on the other - to understand what data are needed to further improve and refine models, created in the first approximation.

\section{Conclusion}

Implementation of the recommendations of the Basel is a relevant way to increase the stability of the banking sector. The Bank of Russia conducts in this direction consistent and systematic work.

A promising direction is the implementation of the internal ratings-based approach, which is based on internal assessments of their borrowers by banks and not on the opinions of rating agencies. Potentially, this approach can significantly reduce the estimate of risk weighted assets, and thereby facilitate satisfaction of the restrictions imposed on the capital adequacy ratio.

At the heart of an advanced approach based on internal ratings, is the notion of probability of default (PD). The world's leading rating agencies (for example, Standard \& Poor's and Moody's) formed a database of defaults on European and American markets. In Russia, there is almost no such information (except for information about individuals defaults that have been accumulated since the establishment of the Central Catalogue of Credit Histories in 2004), that's why an objective assessment of PD is extremely difficult. Statistical information accumulated in Russian banks is distorted, firstly because of the large statistical error due to the fact that defaults of legal entities are quite rare, and secondly, there is a pre-selection of potential borrowers on the level of credit units, by preliminary analysis of documents, interviews with customers, and often personal relationships. Thus, the frequency of credit default among banks' clients is not equivalent to the frequency of default of all potential borrowers.

Therefore, for the implementation of IRB-approach banks need access to a database containing a statistically valid information on historical frequencies of default of different categories of borrowers. Information for such database may be provided by the Federal Tax Service: information about outlawed companies, and tax debtors, as well as the operating companies grouped by industry (sectorial areas of activity), by turnover, by assets and etc. The organizer of the creation of such a database could be the Bank of Russia.

Stress-testing initiative of Russian banks could also contribute to the stability of the Russian banking sector. The position on the need for stress tests already contained in Basel II. Illustrative results of interconnection between key macroeconomic and, for example, corporate indicators are a reliable guide in the refinement of the bank's strategy on the market of targeted products and services. The use of economic and mathematical models of the new generation, based on copula functions, should provide an effective implementation of stress testing. Copulas allow to simulate non-Gaussian distributions of financial risks when the approach, based on the linear correlation, is inadequate. In 2009, the Basel Committee on Banking Supervision noted that copulas are one of the most correct way to assess financial risks (BCBS, 2009).

Yet attempts to fulfil a plan for the implementation of Basel-II/III in Russia have encountered difficulties associated with the need of restructuring the system of quality assessment and risk management in banks.

\section{References}

Akhtaruzzaman, Md. (2009). Potential impact of Basel 2 in developing countries. International Research Journal of Finance and Economics, 23, 46-61.

Astrelina, V. V., \& Miroshnichenko, A. V. (2005). New Basel Agreement. Financial Risk Management Journal, 1, 2-9.

Basel Committee on Banking Supervision (2006, June). International Convergence on Capital Measurement and 
Capital Standards. Comprehensive Version. Retrieved March 3, 2015, from http://www.bis.org/publ/bcbs 128.pdf

Basel Committee on Banking Supervision. (2010, December). Basel III: A global regulatory framework for more resilient banks and banking systems. Retrieved March 3, 2015, from http://www.bis.org/publ/bcbs189_dec 2010.pdf

Basel Committee on Banking Supervision. (2010, December). Results of the comprehensive quantitative impact study. Retrieved March 3, 2015, from http://www.bis.org/publ/bcbs186.pdf

Basel Committee on Banking Supervision. (2010, September). Press release No. 35/2010. "Group of Governors and Heads of Supervision announces higher global minimum capital standards: September 12, 2010". Retrieved March 3, 2015, from http://www.bis.org/press/p100912.htm

Basle Committee on Banking Supervision. (1988, July). International Convergence of Capital Measurement and Capital Standards. Retrieved March 3, 2015, from http://www.bis.org/publ/bcbsc111.pdf

Central Bank of the Russian Federation. (2004). Thesis №254-П "About the procedure of formation of reserves for potential loan losses by credit organizations". Retrieved March 3, 2015, from http://base.consultant.ru/cons/cgi/online.cgi?req=doc;base=LAW;n=173637

Central Bank of the Russian Federation. (2012). Insrtuction №139-И "About required standards of Russian banks". Retrieved March 3, 2015, from http://base.consultant.ru/cons/cgi/online.cgi?req=doc;base=LAW; $\mathrm{n}=175884$

Central Bank of the Russian Federation. (April 2011). Declaration "About strategies of development of bank sector of The Russian Federation till 2015”. Retrieved March 3, 2015, from http://cbr.ru/PSystem/P-sys/ strategy.pdf

Central Bank of the Russian Federation. (December 2012). Letter №192-T «About methodological recommendations concerning the realization of the approach to credit risk measurement on the base of internal banks' ratings". Retrieved March 3, 2015, from http://base.consultant.ru/cons/cgi/online.cgi?req= doc;base $=$ LAW;n=140871

Central Bank of the Russian Federation. (February 2014). Project "Thesis about the procedure of credit risk calculation on the base of internal banks' ratings". Retrieved March 3, 2015, from http://base.consultant.ru $/$ cons/cgi/online.cgi?req=doc;base $=$ PNPA;n=3493; fld $=134 ; \mathrm{dst}=100687 ; \mathrm{rnd}=0.5176681859884411$

Central Bank of the Russian Federation. (February 2014). Project of Recommendations of Bank of Russia "About the procedure of assessment of intercessions concerning application of approach to credit risk measurement on the base of internal banks' ratings". Retrieved March 3, 2015, from http://base.consultant.ru/cons/ cgi/online.cgi?req=doc;base=PNPA; $=3494$; fld $=134$; from=3493-903; rnd $=0.3926422465592623$

Freixas, X., \& Rochet, J.-C. (2008). Microeconomics of banking (2nd ed., p. 363). Cambridge: MIT Press.

Sevruk, V. T. (2010). Methods of measurement and forecast of bank risks. Financial Risk Management Journal, 3, 59-76.

Tysyachnilova, N. A. (2008). Contemporary stage of transformation of Russian bank system to the Basel II. Bank sphere, 11, 38-45.

Zolotarev, V. M. (2005). Measurement of bank risks on the base of contemporary approaches. Financial Risk Management Journal, 3, 67-73.

\section{Copyrights}

Copyright for this article is retained by the author(s), with first publication rights granted to the journal.

This is an open-access article distributed under the terms and conditions of the Creative Commons Attribution license (http://creativecommons.org/licenses/by/3.0/). 